\title{
Seabird mortality induced by land-based artificial lights
}

Airam Rodríguez, ${ }^{1 *}$ Nick D. Holmes, ${ }^{2}$ Peter G. Ryan, ${ }^{3}$ Kerry-Jayne Wilson,,${ }^{4}$ Lucie Faulquier, ${ }^{5}$ Yovana Murillo, ${ }^{6}$ André F. Raine,${ }^{7}$ Jay F. Penniman, ${ }^{8}$ Verónica Neves, ${ }^{9}$ Beneharo Rodríguez, ${ }^{10}$ Juan J. Negro, ${ }^{1}$ André Chiaradia, ${ }^{11}$ Peter Dann,,${ }^{11}$ Tracy Anderson, ${ }^{12}$ Benjamin Metzger, ${ }^{13}$ Masaki Shirai, ${ }^{14}$ Lorna Deppe, ${ }^{15}$ Jennifer Wheeler, ${ }^{16}$ Peter Hodum, ${ }^{17}$ Catia Gouveia, ${ }^{18}$ Vanda Carmo, ${ }^{19}$ Gilberto P. Carreira, ${ }^{19}$ Luis Delgado-Alburqueque ${ }^{20}$ Carlos Guerra-Correa, ${ }^{21}$ François-Xavier Couzi, ${ }^{22}$ Marc Travers, ${ }^{7}$ and Matthieu Le Corre ${ }^{23}$

${ }^{1}$ Department of Evolutionary Ecology, Estación Biológica de Doñana (CSIC), Avda. Américo Vespucio s/n, 41092 Seville, Spain

${ }^{2}$ Island Conservation, 2100 Delaware Avenue, Suite 1, Santa Cruz, CA 95060, U.S.A.

${ }^{3}$ Percy FitzPatrick Institute of African Ornithology, DST-NRF Centre of Excellence, University of Cape Town, Rondebosch 7701, South Africa

${ }^{4}$ West Coast Penguin Trust, P.O. Box 70, Charleston 7865, West Coast, New Zealand

${ }^{5}$ Ornithological Society of French Polynesia, P.O. Box 7023, 98719 Taravao, Tahiti

${ }^{6}$ Ringed Storm-Petrel Project, Joaquín Sorolla 157, Lima 41, Peru

${ }^{7}$ Kauai Endangered Seabird Recovery Project, P.O. Box 81, Hanapepe 96741, Kauai, HI, U.S.A.

${ }^{8}$ Maui Nui Seabird Recovery Project, 4234 Hana Highway, Haiku, 96708-5404, HI, U.S.A.

${ }^{9}$ Department of Oceanography \& Fisheries (DOP), University of the Azores, MARE (Marine and Environmental Sciences Centre), IMAR (Institute of Marine Research), Rua Prof. Dr Frederico Machado 4, PT-9901-862 Horta, Azores, Portugal

${ }^{10}$ Canary Islands' Ornithology and Natural History Group (GOHNIC), La Malecita s/n, 38480 Buenavista del Norte, Tenerife, Canary Islands, Spain

${ }^{11}$ Research Department, Phillip Island Nature Parks, P.O. Box 97, Cowes, Phillip Island, Victoria, 3922, Australia

${ }^{12}$ Save Our Shearwaters, P.O. Box 3330, Lihue, 96766, Kauai, HI, U.S.A.

${ }^{13}$ BirdLife Malta, Flat 2, Xemxija Waterfront Apartments, Triq Is-Simar, Xemxija SPB9025, Malta

${ }^{14}$ Environmental Science Research Laboratory, Central Research Institute of Electric Power Industry, 1646, Abiko, Abiko-shi, Chiba, 270-1194, Japan

${ }^{15}$ The Hutton's Shearwater Charitable Trust, P.O. Box 58 Kaikōura 7340, New Zealand

${ }^{16}$ BirdsCaribbean, 4201 Wilson Blvd 110-174, Arlington, VA 22203, U.S.A.

${ }^{17}$ Oikonos Ecosystem Knowledge, P.O. Box 1918, Kailua, HI 96734, U.S.A.

${ }^{18}$ Portuguese Society for the Study of Birds, Travessa das Torres 2A, $1^{\circ}$ andar, 9060-314 Funchal, Madeira, Portugal

${ }^{19}$ Direção Regional dos Assuntos do Mar; Secretaria Regional do Mar, Ciência e Tecnologia; Governo Regional dos Açores; Colónia Alemã - Apartado 9, 9900-014 Horta, Azores, Portugal

${ }^{20}$ Ringed Storm-Petrel Project, Veterinary Science School, Ricardo Palma University, Av. Benavides 5440, Lima 33, Perú

${ }^{21}$ Centro Regional de Estudios y Educación Ambiental, Universidad de Antofagasta (CREA-UA), 602 Angamos Av., Antofagasta, Chile

${ }^{22}$ Société d'Études Ornithologiques de la Réunion, 13, ruelle des Orchidées 97440 Saint André, La Réunion, France

${ }^{23}$ UMR ENTROPIE, Université de la Réunion 15, avenue René Cassin - CS 9200397744 Saint Denis Cédex 9, La Réunion, France

\begin{abstract}
Artificial lights at night cause high mortality of seabirds, one of the most endangered groups of birds globally. Fledglings of burrow-nesting seabirds, and to a lesser extent adults, are attracted to and then grounded (i.e., forced to land) by lights when they fly at night. We reviewed the current state of knowledge of seabird attraction to light to identify information gaps and propose measures to address the problem. Although species in families such as Alcidae and Anatidae can be grounded by artificial light, the most affected seabirds are petrels and shearwaters (Procellariiformes). At least 56 species of Procellariiformes,
\end{abstract}


more than one-third of them (24) threatened, are subject to grounding by lights. Seabirds grounded by lights have been found worldwide, mainly on oceanic islands but also at some continental locations. Petrel breeding grounds confined to formerly uninhabited islands are particularly at risk from light pollution due to tourism and urban sprawl. Where it is impractical to ban external lights, rescue programs of grounded birds offer the most immediate and employed mitigation to reduce the rate of light-induced mortality and save thousands of birds every year. These programs also provide useful information for seabird management. However, these data are typically fragmentary, biased, and uncertain and can lead to inaccurate impact estimates and poor understanding of the phenomenon of seabird attraction to lights. We believe the most urgently needed actions to mitigate and understand light-induced mortality of seabirds are estimation of mortality and effects on populations; determination of threshold light levels and safe distances from light sources; documentation of the fate of rescued birds; improvement of rescue campaigns, particularly in terms of increasing recovery rates and level of care; and research on seabird-friendly lights to reduce attraction.

Keywords: disorientation, illumination, light pollution, orientation, petrel, rescue campaign

Mortalidad de Aves Marinas Producida por Luces Artificiales Terrestres

Resumen: Las luces artificiales nocturnas causan una mortalidad alta de aves marinas, uno de los grupos de aves en mayor peligro de extinción a nivel mundial. Los polluelos de aves marinas que anidan en madrigueras, $y$ en menor medida los adultos, son atraídos y forzados a aterrizar por las luces cuando vuelan de noche. Revisamos el estado actual del conocimiento sobre la atracción de las aves marinas por la luz para identificar vacíos de información y proponer medidas para resolver el problema. Aunque las especies de familias como Alcidae y Anatidae pueden ser forzadas a aterrizar por la luz artificial, las aves marinas más afectadas son los petreles y las pardelas (Procellariiformes). Por lo menos 56 especies de Procellariiformes, más de un tercio (24) de ellas amenazadas, son propensas al aterrizaje atraídas por las luces. Las aves marinas forzadas a aterrizar han sido halladas en todo el mundo, principalmente en islas oceánicas, pero también en algunas localidades continentales. Los sitios de anidación de los petreles confinados anteriormente a islas deshabitadas están particularmente en riesgo de sufrir contaminación lumínica debido al turismo y al crecimiento urbano. En donde no es práctico probibir las luces externas, los programas de rescate de las aves accidentadas ofrecen la mitigación más inmediata y empleada para reducir la tasa de mortalidad inducida por la luz y salvar a miles de aves cada año. Estos programas también proporcionan información útil para el manejo de aves marinas. Sin embargo, estos datos están típicamente fragmentados, sesgados y son inciertos, y pueden llevar a estimaciones inexactas del impacto y a un entendimiento pobre del fenómeno de la atracción de las aves marinas por la luz. Creemos que las acciones necesarias de mayor urgencia para mitigar y entender la mortalidad de aves marinas producida por la luz son: la estimación de la mortalidad y los efectos sobre la población; la determinación de umbrales de niveles de luz y de distancias seguras a las fuentes de luz; el estudio del destino de las aves rescatadas; la mejora de las campañas de rescate, particularmente en términos de incrementar las tasas de recogida y el nivel de cuidado; y la investigación sobre las características de la luz para reducir la atracción de las aves marinas.

Palabras Clave: campaña de rescate, contaminación lumínica, desorientación, iluminación, orientación, petrel

\section{Introduction}

The alteration of natural light levels in the environment, or light pollution, has increased dramatically over the last century and has led to the loss of natural nightscapes worldwide (Bennie et al. 2015; Gaston et al. 2015a) and affected, for example, individuals' health, populations' time partitioning, interspecific interactions, reproduction, movements, and community structure, thereby causing cascade effects on ecosystem functioning (Longcore \& Rich 2004; Gaston et al. 2014, 2015b). Accordingly, light pollution is recognized as a great threat to biodiversity (Hölker et al. 2010). One of the most severe ecological consequences of light pollution is lightinduced mass fatality events.
Seabirds are among the most endangered groups of birds globally, and Procelariiformes (hereafter petrels) has one of the highest proportions of threatened species (Croxall et al. 2012). The principal threats at sea are commercial fishery operations (e.g., competition and bycatch) and pollution (e.g., oil spills, marine-debris ingestion, and entanglement). On land introduced predators and habitat loss can severely impact breeding colonies (Croxall et al. 2012). The widespread and ever-growing use of artificial light at night is an increasing threat to seabirds. Burrow-nesting petrels are attracted to artificial lights at night, become disorientated, and are forced to land (Imber 1975). This phenomenon, called fallout (Reed et al. 1985), can cause mass-mortality events (Telfer et al. 1987; Ainley et al. 2001; Le Corre et al. 


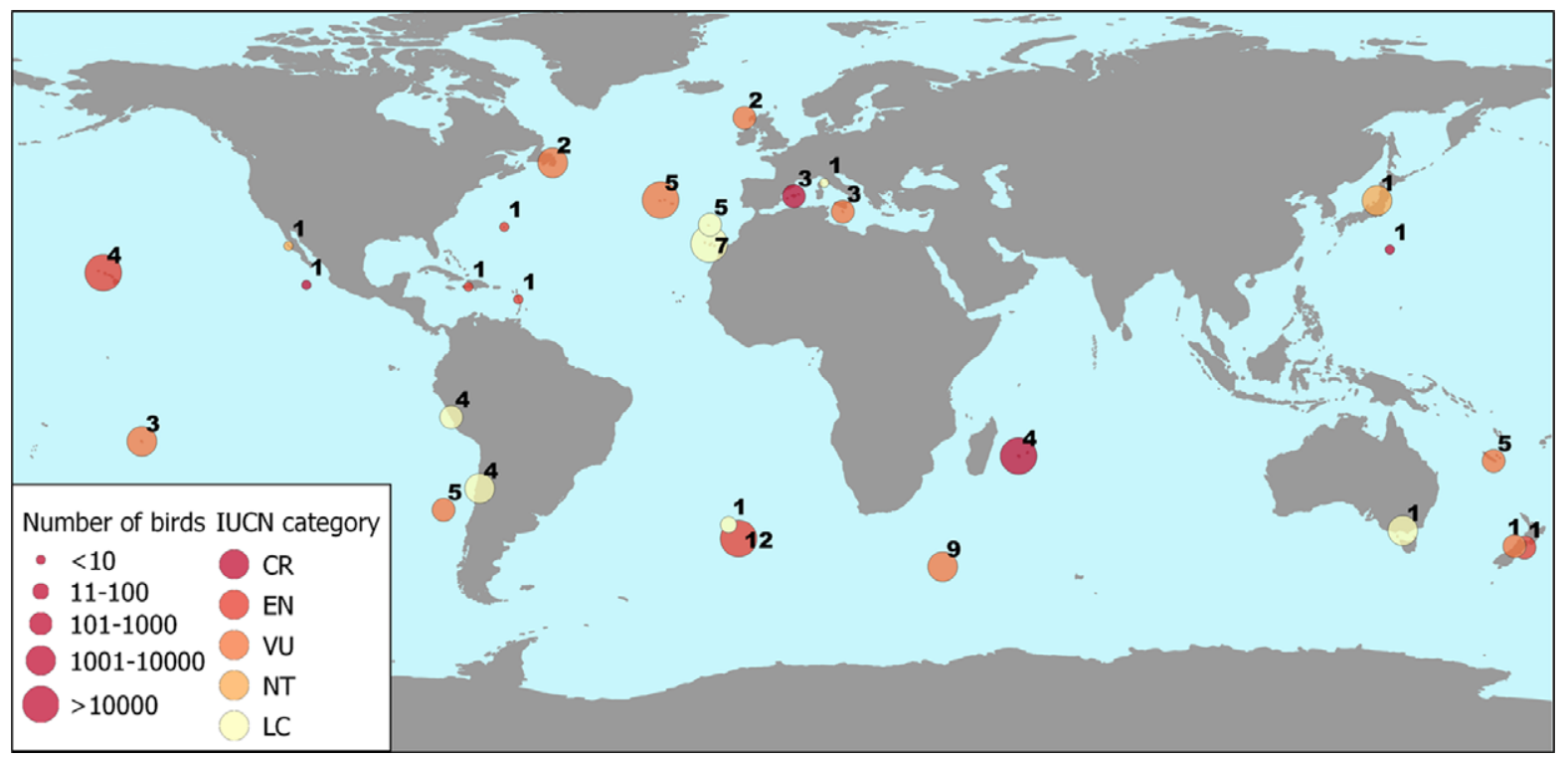

Figure 1. Locations where attraction of seabird fledglings to lights has been reported (numbers, number of species affected; circle size, proportional to number of grounded birds; CR, critically endangered; EN, endangered; VU, vulnerable; NT, near threatened; LC, least concern).

2002; Rodríguez \& Rodríguez 2009; Rodríguez et al. 2014). Light-induced grounding can be fatal due to collisions with human-made structures (e.g. buildings, electric wires and pylons, fences, or posts) or the ground. Even if uninjured, grounded birds may be unable to take off again and are vulnerable to predation; vehicle collisions (Rodríguez et al. 2012b, 2014); starvation or dehydration (Rodríguez et al. 2012b); and poaching (some people eat grounded birds) (M.L-C., personal observation).

We reviewed the state of knowledge and the global impact of seabird mortality induced by land-based artificial light. Specifically, we focused on the global distribution and scale of impacts to seabird species; what is known after four decades of seabird rescue and rehabilitation campaigns worldwide; and what information is needed to better assess and mitigate this growing threat.

\section{Information Sources}

To determine the taxonomic diversity of seabirds affected by lights, we consulted the IUCN Red List of Threatened Species website (IUCN 2016) and searched for species affected by light pollution. We refined our search with the terms Aves and light pollution (within excess energy, pollution, and threats categories). We found 15 species assessments: 13 petrels, 1 auklet, and 1 thrush (Supporting Information). We also searched Web of Science for peer-reviewed literature on seabird attraction to light by combining targeted keyword searches (light pollution, artificial light*, seabird*, marine bird*, light*, mortality, attraction, and disorientation). We classified publications as of interest if they dealt with seabird mortality induced by artificial lights and as terrestrial or marine, depending on whether mortality, attraction, or disorientation was caused by land- or marine-based lights. Twenty-one of the 100 publications that emerged from our search at Web of Science dealt with light-induced mortality of seabirds. Fourteen publications were classified as terrestrial and 7 as marine (Supporting Information). Our list was not exhaustive, but it reflected the information available for different taxa. To expand our search, we examined the references in the publications of interest, as well as their citations, and found 9 additional publications.

Rescue efforts (defined as actions taken to recover birds grounded by light attraction, mitigate threats associated with light-induced grounding [road kills, predation, dehydration, starvation, or poaching], and release birds to the ocean) constitute an information source because data collection has been instituted for some projects. We used the internet and social media (Google, Facebook, and Twitter) to search for programs in which citizens are encouraged to rescue and report on grounded birds. We asked them for information on the number of species and individuals, proportion of ages, proportion of the population affected, and mortality rates.

\section{Location, Species, and Age of Grounded Birds}

We found that light-induced fatality of seabirds has been recorded on at least 47 islands worldwide, on three continental locations, and across all oceans (Fig. 1). 


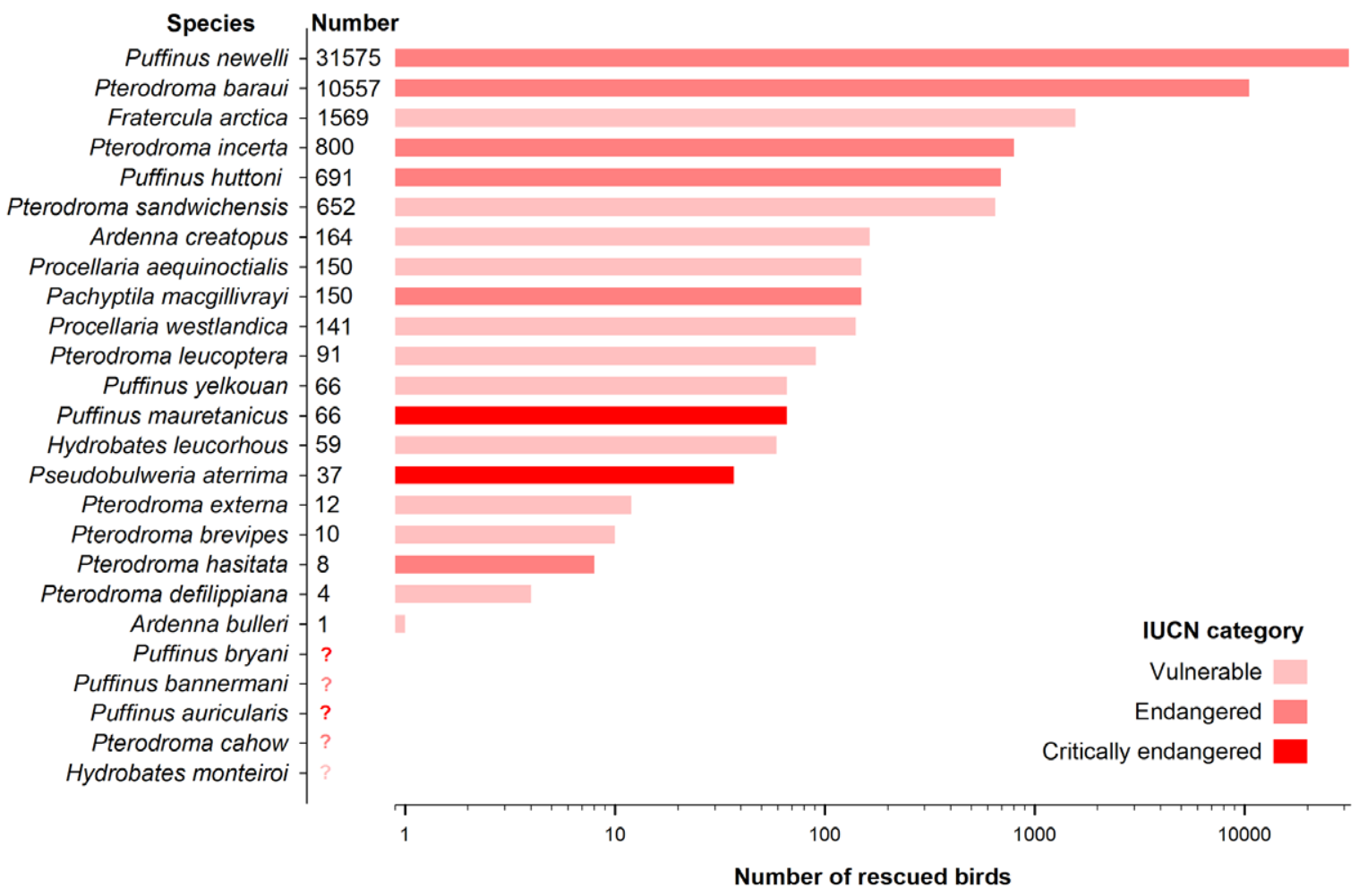

Figure 2. Threatened seabirds (IUCN 2014) affected by light-induced mortality on land (numbers on y-axis, number of grounded birds dead and alive; question mark, species reported to be grounded by light but without quantification).

This phenomenon affects mainly burrow-nesting petrel species (Procellariidae, Hydrobatidae, and Oceanitidae), although other seabirds such as auklets and puffins (Alcidae) and eiders (Anatidae) can also be affected (Dick \& Donalson 1978; Whitworth et al. 1997; Merkel \& Johansen 2011; Wilhelm et al. 2013). The disproportionate effect on petrels was supported by the scant information on other species. Only 1 of 14 publications classified as terrestrial, and 2 of 15 IUCN species assessments dealt with species other than petrels. Fifty-six of 113 burrownesting petrel species have been recorded grounded by lights, an estimate more than double the number reported in previous publications (Reed et al. 1985) and four times higher than the number of species for which this is listed as a problem by IUCN. Twenty-four seabird species subject to light-induced grounds are globally threatened (Fig. 2 \& Supporting Information). Attraction to and disorientation by lights of seabirds at sea have also been reported (7 studies report light mortality, attraction, or disorientation at sea), primarily in association with lights being used for fisheries purposes (Ryan 1991; Black 2005; Merkel \& Johansen 2011; Glass \& Ryan 2013) but also with lights on oil platforms (Wiese et al. 2001; Day et al. 2015; Ronconi et al. 2015). Light-induced mortality at sea is difficult to document (Montevecchi 2006); thus, assessments may be underreported relative to estimates of land-based mortality.
Of the 14 studies focused on light-induced fatalities on land, all documented a greater number of fatalities of fledglings than of adults. Most seabirds affected are fledglings grounded during their first flights from their natal nests toward the ocean. The percentage of affected fledglings in relation to all grounded birds (i.e., fledglings + adults) varies among species from $68 \%$ to $99 \%$ (Table 1). Rescue programs that target fledglings and collect data on age probably underestimate the number of adults involved, but at most sites it appears fewer adults are affected (Table 1). Thus, presumably, the main functional consequence of light-induced fatality on land is reduced survival after fledging. However, rescue programs should ensure that adults are not ignored by not restricting rescues to the fledging season and by quantifying adult mortality. At sea, light attraction may involve adults and juveniles because some events occur outside fledging periods. None of the 7 marine studies considered the age of birds.

\section{Reasons for Light-Induced Grounding}

The reasons for seabird attraction to and disorientation by lights are not well known. Three hypotheses have been proposed. First, artificial light is perceived by birds as a 


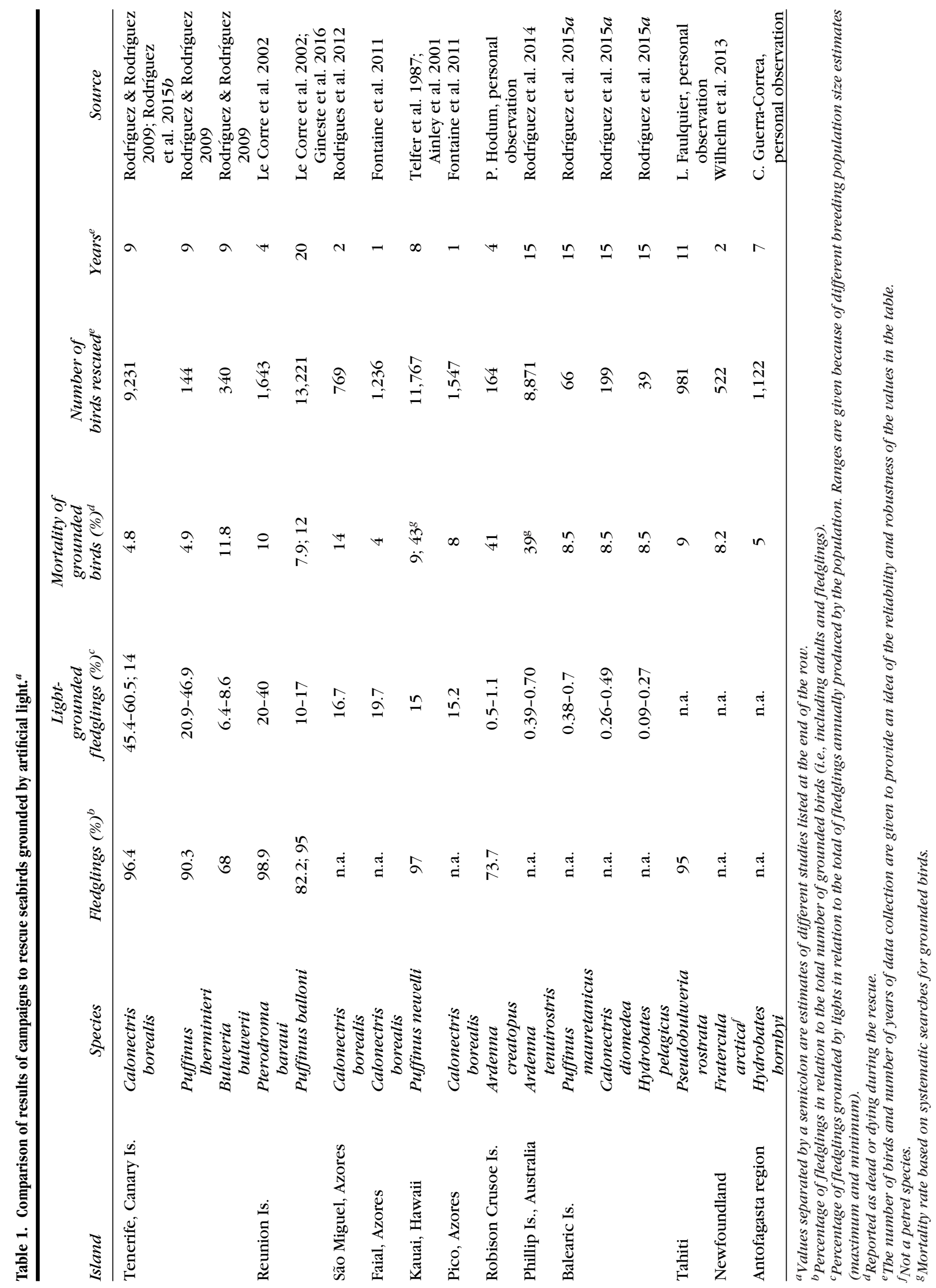


source of food (i.e., bioluminescent prey). Procellariiform chicks are fed by regurgitation, but they do not receive parental care after fledging. Thus, they must learn to find food for themselves at sea. Some species grounded by lights consume bioluminescent prey, and inexperienced fledglings may confuse artificial lights for their natural bioluminescent prey (Imber 1975).

Second, for the first months of life, the only light cavity-nesting seabirds see is light streaming in from the burrow entrance. All a nestling's meals, brought by the parents, also arrive via that entrance; thus, food is associated with light and newly fledged birds might confuse artificial lights with a food source (D. Ainley, personal communication).

Third, artificial lights could override the ambient light of the moon, stars, or other stellar objects near the horizon. Thus, seabirds could lose the visual cues needed for finding the ocean, or even incorrectly use artificial lights as navigational cues (Telfer et al. 1987). In support of this hypothesis, generally seabirds do not crash directly into lights as they would do if they had confused them for prey. When they fly over lit areas or near bright lights, they seem blinded or disoriented and collide with structures such us walls, antennas, trees, or the ground. The fact that the number of grounded birds is lower when the moon is full, when artificial lights are less prominent relative to moonlight, also supports this hypothesis. The low contrast between artificial lights and the night sky during a full moon may make artificial lights less attractive to inexperienced seabirds looking for food, which also supports the food-source hypotheses. However, food-source hypotheses do not explain why birds older than fledglings also are affected.

\section{Mitigation Measures}

The impact of light pollution on seabirds can be reduced following a hierarchical mitigation plan organized (IUCN 2014) around the following actions: avoidance, minimization, rehabilitation, offsets, and supporting of conservation actions.

\section{Avoidance}

Avoidance entails measures taken to avoid creating impacts. In planning of new developments, avoidance includes identifying and not deploying light systems associated with bird groundings. For existing developments, unnecessary lights are removed or turned off when they are spatially and temporally unnecessary (Table 3). Obviously, the best way to mitigate light attraction is to remove all sources of artificial light. This is impractical in most areas, but virtually all external lights can be eliminated in some situations, such as small research stations on remote islands. For example, the number of birds af- fected on Marion and Gough Islands was greatly reduced once outside lights were removed and all windows were fitted with blackout blinds that are closed each evening before full dark (Cooper \& Ryan 1994). Reducing the use of lights at night has also greatly reduced collisions with vessels fishing around seabird breeding islands (Glass \& Ryan 2013).

\section{Minimization}

Minimization measures reduce the duration, intensity, or extent of the effects of artificial lights on seabirds. Removing all external lights in urban areas is difficult due to human safety concerns. Some progress has been made, nonetheless, in sparsely populated rural areas, such as Cilaos, Reunion, Indian Ocean, where streetlights are turned off during the fledging period of the Barau's Petrel (Pterodroma baraui) (M.L-C., personal observation). On Kauai, Hawaii, to avoid attracting Newell's Shearwaters (Puffinus newelli) to light, recreational events that previously occurred at night are being held during daylight hours (The Associated Press 2010) and legal action is underway to remove of unnecessary lights (Department of Justice 2010). Even though complete removal of external lighting is unpopular or impractical, reducing light emissions (i.e., turning off or shielding lights) can help limit the number of affected birds. Shielding and other light-source manipulations seek to achieve necessary illumination for humans while reducing light emissions visible to birds (e.g., reducing light projected toward the sky or onto reflective surfaces and automated features to turn off lights when they are not required) (KSHCP 2016). The number of grounded Newell's Shearwaters decreased by $40 \%$ when the main lights of a tourist resort at Kauai were shielded (Reed et al. 1985). On St Kilda Island, Scotland, reduced light emissions resulted in a decrease in the numbers of grounded Leach's StormPetrels (Hydrobates leucorbous) but not Manx Shearwaters (Puffinus puffinus) (Miles et al. 2010). Turning off streetlights along the 600-m-long bridge connecting Phillip Island to the Australian mainland reduced the number of grounded Short-tailed Shearwaters (Ardenna tenuirostris) (Rodríguez et al. 2014).

Identifying key temporal and spatial overlaps between seabirds and lighting is necessary to minimize risk. On a seasonal scale, it includes focusing measures on the time of year when fledgling occurs. On a nightly scale, minimizing light during the first few hours of darkness appears to reduce the attraction of fledglings of some species, although the timing of fledging is not well known for most seabird species (i.e. early or late at night). Most Cory's Shearwater (Calonectris borealis) fledglings GPS-tracked and grounded in lit areas initiate their flights toward the ocean during the first hours of darkness (Rodríguez et al. 2015b), coinciding with times of peak light pollution. Also on Kauai, the number of grounded Newell's 
Shearwater fledglings reached a peak 2-3 hours after sunset (Reed et al. 1985). Thus, it seems that the benefits of partial night lighting (i.e., lights being switched off or dimmed when human activity is lower) could be limited for petrels, as for some bat species (Azam et al. 2015; Day et al. 2015).

Another way to minimize the number of grounded birds may be to change the spectral composition of lights, as it has been done for passerines (Poot et al. 2008; Doppler et al. 2015), although evidence for seabirds is scarce (Reed 1986, 1987). On Reunion Tropical Shearwaters (Puffinus bailloni) seem to be less attracted to red and yellow lights than to green and blue lights (Salamolard et al. 2007). On the Juan Fernández Islands, Chile, white streetlights around seabird colonies have been changed to red and recently to green lights, and grounding rates appear to have declined, although on a small spatial scale (P.H., personal observation).

\section{Rehabilitation}

Rehabilitation of individuals grounded by artificial light is a common feature of rescue campaigns. Rescue and rehabilitation reduce light-induced fatalities by reducing risk of death from predation, vehicle collision, or starvation and dehydration after grounding. Implementation and coordination of these programs vary among locations, but typically the general public takes grounded birds to designated rescue stations (e.g., fire or police station, town hall, or collaborating entities) or report them to qualified personnel. In small areas or nature parks, rescues can be conducted by qualified personnel directly (Miles et al. 2010; Rodríguez et al. 2014). After assessment of their condition, collected birds are released from seaside cliff tops in daylight or in a colony at night. To encourage participation and to raise awareness among lay people, dissemination and outreach activities are conducted that involve news stories; advertisements in local media, cinemas, social networks, and online; seminars and talks in primary and high schools; distribution of posters, stickers, and T-shirts; and publicity regarding releases of rescued birds.

The first rescue program was established in 1978 on Kauai (Telfer et al. 1987) and, since then, programs have been established in 16 locations for 34 species (Fig. 1 $\&$ Supporting Information). Thousands of seabirds have been collected and released by program participants (Table $2 \&$ Supporting Information), and mortality rates for the populations involved have been reduced. The absence of these programs would increase mortality rates, and modeling studies suggest that not having these programs may affect populations negatively (Ainley et al. 2001; Fontaine et al. 2011; Griesemer \& Holmes 2011). For the Tropical Shearwater, the rescue and release of 11,638 fledglings during the last 20 years is believed to have played an important role in maintaining a stable population (Gineste et al. 2016). These rescue programs alone are not an adequate response to the threat of fallout because not all birds subject to fallout are collected by these programs, not all birds collected survive, and postrelease survival of fallout birds remains largely untested.

\section{Offsets}

Offsets compensate for adverse impacts that cannot be avoided or minimized and for birds or areas that cannot be rehabilitated. Offsets should be implemented once avoidance, minimization, and rehabilitation measures have been exhausted (IUCN 2014). Examples of such compensatory actions include the control of predators at colonies (Holmes et al. 2016), shielding of coastal powerlines by planting trees (D. Ainley, personal communication), burying of powerlines near breeding areas (P.D., personal observation), provision of additional nesting habitat (e.g., artificial nests), and restoration of degraded breeding habitat to compensate for light-induced mortality by increasing breeding success and breeding habitat.

\section{Supporting Conservation Actions}

Actions that support conservation have positive effects but the level of effect is difficult to quantify. The qualitative outcomes of such measures do not fit easily into the mitigation hierarchy but may provide crucial support to the reduction of the effects of light pollution when they provide pertinent information on species' ecology or assess the effectiveness of management actions (The Biodiversity Consultancy 2016). On Kauai and Reunion, electricity companies have funded rescue programs and research to improve knowledge of the affected species and threats to these species (Ainley et al. 2001; Le Corre et al. 2002, 2003; Day et al. 2003). Ecotourism based on the seabirds affected by grounding may also lead to reductions of light-induced mortality. The added value of ecotourism to local economies could favor conservationoriented lighting policies that otherwise would be opposed by local residents.

\section{Estimating the Magnitude of the Problem}

Quantifying the magnitude of fallout (i.e., the proportion of fledglings grounded by lights each year) and lightinduced mortality is critical for the conservation and the management of susceptible species (Le Corre et al. 2002). The majority of existing data come from rescue programs, for which the goal is remedial action by the community not necessarily systematic monitoring. Obtaining accurate information is difficult and data are usually biased for several reasons. 


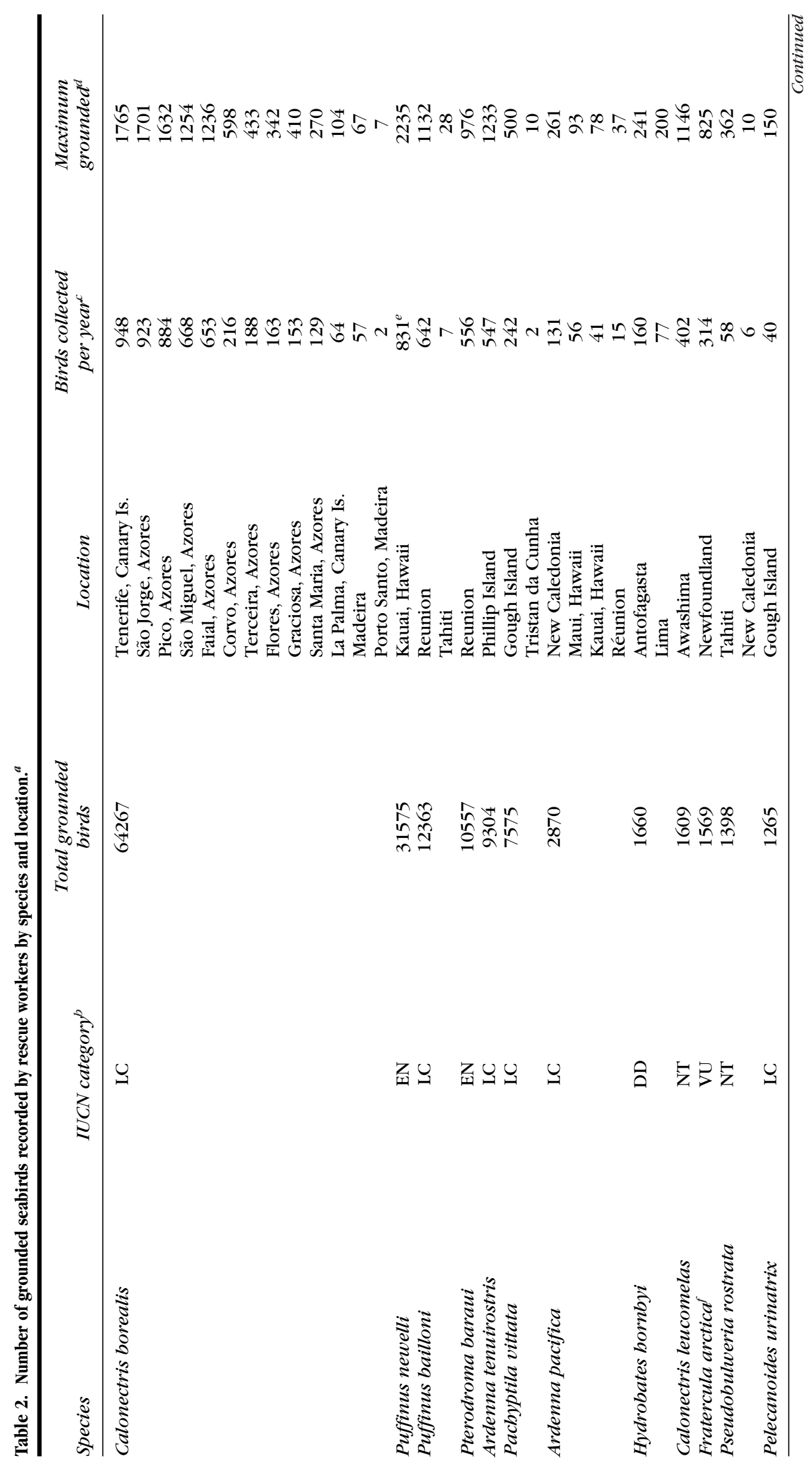




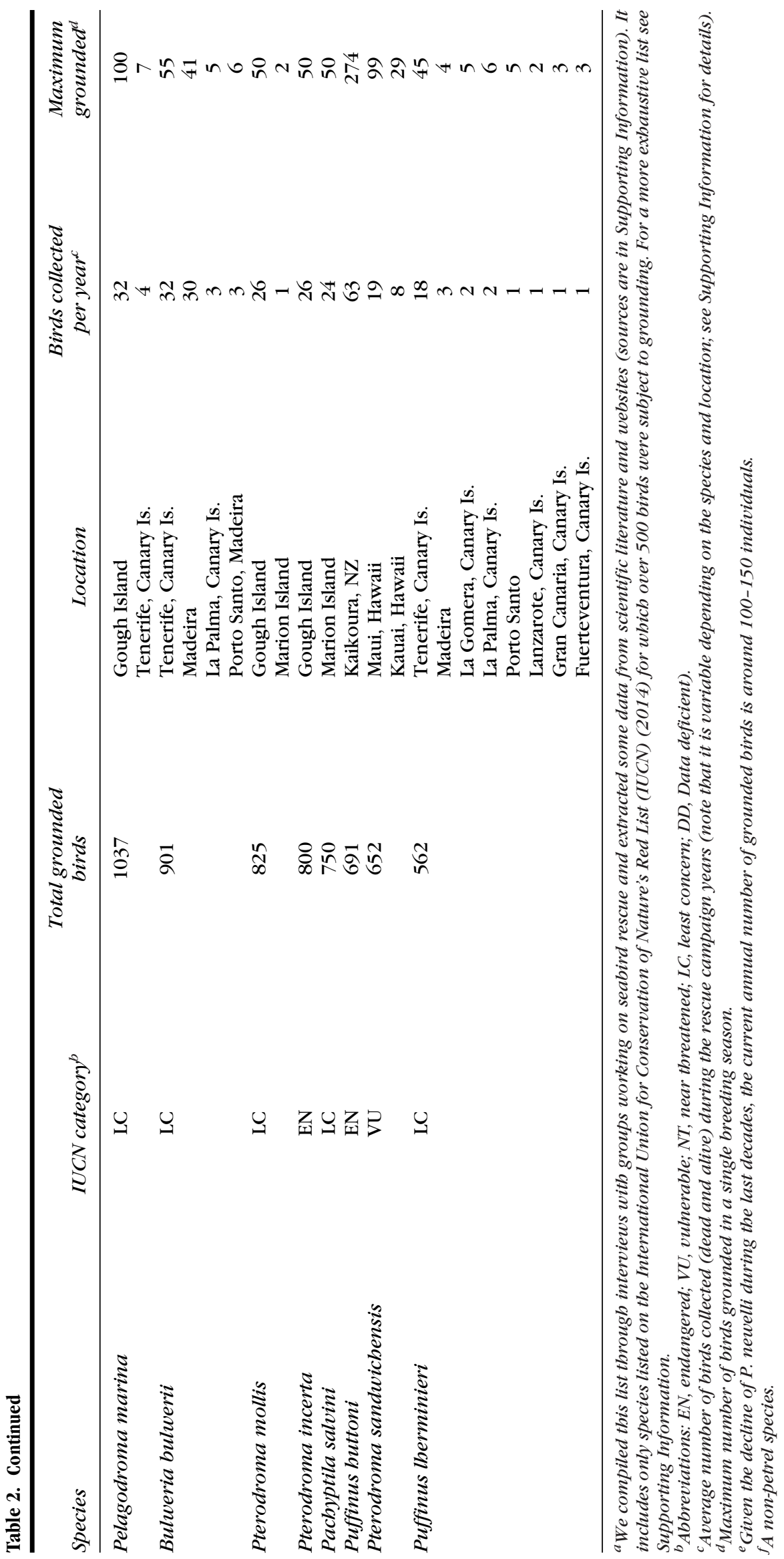




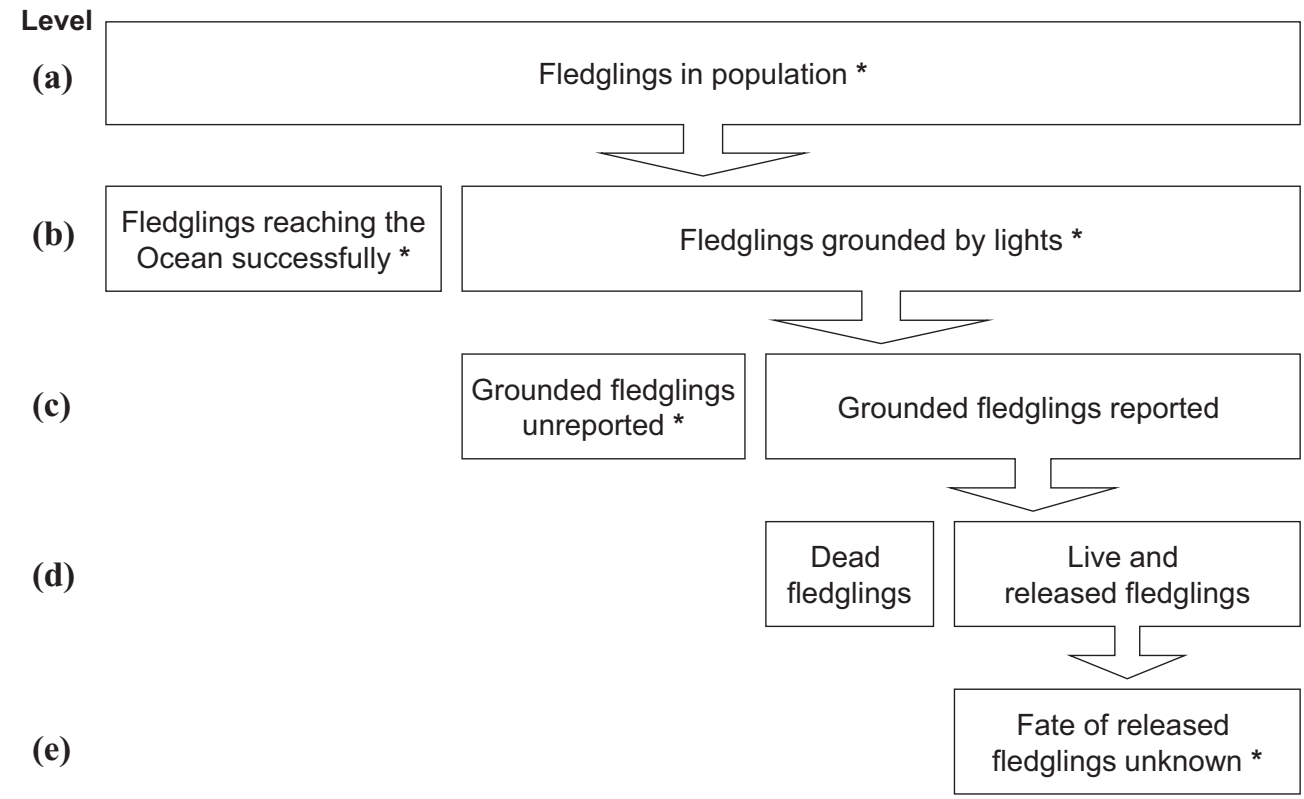

Figure 3. Hierarchical levels of sources of uncertainty in the estimation of the impact of light pollution on seabirds. Length of bar at A represents the total number of fledglings produced annually at the population. In subsequent levels, the boxes represent equal or lower numbers of fledglings than at level a $\left(^{*}\right.$, steps where estimating the number with accuracy is difficult).

The number of fledglings produced by a population is hard to estimate for many affected species (Fig. 3, level a). Colony locations are not always known and when they are known estimating breeding success without substantial disturbance of birds is hindered by the birds' nocturnal, cryptic, and burrow-nesting behavior. For some species, nest chambers are difficult to reach, multiple burrows may have a single narrow entrance, and colonies are often located in remote and inaccessible places (Brooke 2004).

The number of grounded fledglings is hard to record accurately and is consequently underreported (Fig. 3, level b). The real number of fledglings grounded by lights (Fig. 3, level b) must be at least equal to the number of grounded fledglings reported on the rescue campaigns (Fig. 3, level c). Accuracy of grounding numbers depends on the rescue effort. Determining the number of grounded fledglings requires an effective monitoring program that defines the area of impact, the search area, the probability of a carcass being found, and how quickly a bird may disappear due to predation, scavenging, or decay. Rescue campaigns are usually conducted by volunteers; thus, their success depends on public awareness. On Tenerife, Canary Islands, very few petrels of three species were reported during the first 2 years of implementation of a rescue program, likely due to a lack of awareness by the general public during that period (Rodríguez et al. 2012c). Such a pattern is not uncommon and has been reported in other long-term programs, such as those on Kauai and Reunion (Telfer et al. 1987; Le Corre et al. 2002). Grounded fledglings tend to spend daylight hours hiding in dense vegetation, holes, or crevices and are thereby easily overlooked by rescuers (Reed et al. 1985). Smaller seabird species (such as Storm-Petrels) may be harder to find and consequently may be substantially underrepresented in data sets.

Systematic searches for birds conducted by qualified personnel can increase the proportion of dead birds found during rescue campaigns (Fig. 3, levels c and d) because lay people may be less likely to report dead birds either because they are not aware of the importance of doing this or because corpses are less visible or unpleasant to handle (wet, bloody, decomposing, malodorous). On Kauai opportunistic surveys via the general public rescue program for Newell's Shearwaters identified $7.7 \%$ mortality of the collected birds, whereas systematic searches revealed 43\% mortality (Podolsky et al. 1998; Ainley et al. 2001). On Phillip Island, Australia, systematic searches revealed a higher mortality (39\%) of short-tailed Shearwater fledglings than in other opportunistic rescue programs (Table 1) (Rodríguez et al. 2014).

From an environmental management point of view, assessing the fate of rescued fledglings once they released into the wild is crucial, but studying this topic is challenging because of long-term recruitment and inaccessibility to colonies and nests. Thus, the fate of recovered fledglings is unknown (Fig. 3, level e) even though thousands of birds have been banded and released during rescue campaigns (Ainley et al. 2001). Some birds rescued and banded at rescue programs as fledglings have 
recruited as breeders (A.R., M.L-C., and A.F.R., personal observations), but these observations are too anecdotal to allow for recruitment estimates. However, they demonstrate that an unknown proportion of grounded birds survive after being released.

Despite these sources of uncertainty, rough estimates of the proportions of populations affected have been made based on the number of grounded fledglings reported and estimates of breeding population size and breeding success (the latter 2 normally taken from the literature). Some studies use correction factors to control for unreported birds, either dead or never found (Podolsky et al. 1998). Estimates of the percentage of fledglings affected vary from $0.1 \%$ to $60.5 \%$ of annual production, although these numbers are rarely estimated empirically (Table 1).

Petrels are long-lived species; consequently, the most important threats are those that affect adult survival (Brooke 2004). However, light-induced mortality of fledglings is a fatality source, which, in addition to other threats, could threaten the survival of some petrel populations (Simons 1984; Ainley et al. 2001; Fontaine et al. 2011; Griesemer \& Holmes 2011). To quantify the impact of light pollution relative to other threats, population models have been used for the Hawaiian Petrel (Simons 1984), Newell's Shearwater (Ainley et al. 2001; Griesemer \& Holmes 2011), and Cory's Shearwater (Fontaine et al. 2011). These models identified significant impacts to population growth rates when fallout threats were considered alone, primarily because of the number of birds expected to be subject to this threat as a proportion of the total population.

\section{Temporal and Spatial Distribution of Fallout}

Fallout predominantly coincides with the fledging season of the affected species. Numbers grounded usually show a normal distribution throughout the fledging season, corresponding with the population spread of fledging dates. The most important factor affecting this pattern is moon phase; fewer birds are grounded when the moon is full than when there is a new moon (Telfer et al. 1987; Le Corre et al. 2002; Rodríguez \& Rodríguez 2009; Miles et al. 2010; Murillo et al. 2013; Rodríguez et al. 2014). As a result, the total number of grounded birds in a season is generally lower when the full moon coincides with the peak of fledging (Ainley et al. 2001; Rodríguez et al. 2012c).

Rescue campaigns also show where most grounded birds fall out (Ainley et al. 2001; Troy et al. 2011, 2013; Rodríguez et al. 2012c). In general, most grounded birds are found in well-lit coastal areas (Rodríguez \& Rodríguez 2009; Rodrigues et al. 2012; Laguna et al. 2014; Rodríguez et al. 2015a), although some species are grounded at high elevations (e.g., Barau's Petrel and Mascarene Black Petrel
[Pseudobulweria aterrima] at $1500 \mathrm{~m}$ asl on Reunion [Le Corre et al. 2002, 2003; Riethmuller et al. 2012]; Ringed Storm-Petrel [Hydrobates hornbyi] at $3052 \mathrm{~m}$ asl on Huaraz in the Andes [Y.M., personal observation]). Efforts to model the spatial fallout distribution generally show positive relationships with light pollution levels taken from satellite imagery (Rodrigues et al 2012; Troy et al. 2011, 2013). The spatial distribution of breeding colonies and their proximity to lit areas (directly adjacent or on transit routes out to sea) also plays a crucial role in determining the severity of the light-induced impact on seabirds. Fledglings from inland colonies typically are more likely to be grounded by lights than birds hatched in colonies located on seaward cliffs or slopes (Rodríguez et al. 2015a, 2015b). Some fledglings could reach the ocean and be attracted back to land by coastal lights (Baccetti et al. 2005; Rodríguez et al. 2014). In some cases, this type of attraction may be a large proportion of total fallout on the island (Troy et al. 2013). However, tracked flights of Cory's Shearwater fledglings from nests to grounding locations suggest birds were grounded on the night they fledge and very close to their natal burrows (Rodríguez et al. 2015b).

\section{Making the Most of Rescue Programs}

Rescue programs help mitigate light-induced mortality, but alone they cannot completely eliminate fatalities. Rescue programs also represent opportunities to advance conservation knowledge for poorly known or rare species. Such knowledge would otherwise be too expensive or intractable to acquire. For many years, the best evidence of reproduction for many rare petrel species came from birds grounded by artificial lights (e.g. Mascarene Black Petrel on Reunion [Le Corre et al. 2003; Riethmuller et al. 2012], Tahiti Petrel (Pseudobulweria rostrata) on Tahiti [Villard et al. 2006], and Manx Shearwater on Tenerife [Rodríguez et al. 2008]). The breeding grounds of the Ringed Storm-Petrel have never been found (Brooke 2004), but it is known from grounded fledglings delivered to rehabilitation programs in Peru and Chile that its fledging season is April-July (Murillo et al. 2013), which provides useful guidance on the appropriate time to search for its enigmatic breeding sites.

Because of the remoteness and inaccessibility of the colonies of some rare and secretive petrel species, ground-based population monitoring is limited. Records of the number of fledglings reported by rescue campaigns can be used as a population index because they reflect overall population size (number of fledglings produced cannot exceed the number of breeding pairs because petrels lay $1 \mathrm{egg} / \mathrm{breeding}$ attempt) and breeding success (a small number of fledglings could indicate a year of poor breeding success) (Day et al. 2003). Thus, declining trends in the number of grounded fledglings have 
been interpreted as indicative of declining populations. On Kauai, Newell's Shearwater numbers have decreased on some parts of the island, a trend probably related to a reduction in breeding pairs or extirpation of nearby colonies (Ainley et al. 2001; Day et al. 2003). On Tenerife, the number of Macaronesian Shearwaters (Puffinus lherminieri baroli) rescued has decreased since rescue campaigns started, suggesting its population is declining (Rodríguez et al. 2012c). However, an increase in the number of grounded birds is difficult to interpret because, usually, light-pollution levels and public awareness increase in parallel with reported numbers. Thus, the increases of Newell's Shearwaters recovered from the north shore of Kauai during the 1980s and Cory's Shearwaters on Tenerife from 1990 to 2010 were interpreted as a consequence of increasing urbanization and greater public awareness rather than an increase in breeding population or reproductive success (Ainley et al. 2001; Rodríguez et al. 2012c).

Despite light- emission reductions, enhancement of rescue campaigns, and other mitigation measures, artificial lights will inevitably cause fatalities. The fledglings that die constitute a homogeneous sample that can provide information on marine processes during the period they were raised because fledglings grounded during a given season belong to the same cohort. Thus, they could be used as indicators of marine environmental condition in long-term monitoring programs on epidemiology, pollution, marine productivity, or foraging ecology. Dead Cory's Shearwaters have been used to study plastic ingestion. Results of these studies show that parents transfer marine litter to fledglings and demonstrate plastic contamination in the food web of a human-exploited ecosystem (fishing), the Canary Current (Rodríguez et al. 2012a). Similarly, dead Newell's Shearwaters have provided insights into the diet and plastic ingestion of this endangered species (Ainley et al. 2014; Kain et al. 2016).

\section{Future Research}

As our findings emphasize, attraction of seabirds to artificial lights is poorly understood. Future research should focus on the following key areas: biology and ecology of susceptible species; effects of light intensity and spectra on grounding; improving rescue effort and rehabilitation and fate of rescued birds.

A lack of information on the biology and ecology of susceptible species is a primary problem. Without basic information on the location of colonies, breeding population sizes, and reproductive success, it is difficult to estimate the severity of light-induced mortality (Fig. 3). Intensive monitoring programs have shed some light on these topics for some species such as the Newell's Shearwater on Kauai and Barau's Petrel and Mascarene Black Petrel on Reunion.
In the absence of better information, light intensity has been mapped by nocturnal satellite imagery to better understand spatial fallout patterns (Rodrigues et al. 2012; Troy et al. 2011, 2013; Rodríguez et al. 2015a, 2015b). Although a higher impact, measured as the number of grounded fledglings, has been observed in areas with much light pollution (Rodrigues et al. 2012; Troy et al. $2011,2013)$, the potential relationship between light intensity and the distance over which birds are attracted is poorly known because of the difficulty in tracking birds. For Cory's Shearwater fledglings on Tenerife, a positive correlation between light intensity and flight distance from nests to grounding location is reported (i.e., stronger lights attracted birds from farther away [Rodríguez et al. 2015b]). Understanding the relationship between light intensity and the distance over which birds are attracted has important implications for the management of the problem because it would allow quantification of the exposure of dark areas and colonies to light pollution.

Artificial lights are usually mapped in terms of light intensity with respect to human vision, but attention also needs to be paid to the spectra of lights responsible for seabird groundings. Given the differences in light sensitivity between seabirds and humans (Reed 1986), finding appropriate light spectra that minimize the stimulation of seabird photoreceptors may reduce the number of birds grounded by lights (studied in passerines [Poot et al. 2008; Doppler et al. 2015]). However, taxonspecific responses to light spectra and colors likely exist. Light characteristics that reduce the attraction for some avian groups (e.g. green lights for passerines [Poot et al. 2008]) may be more attractive to seabirds. Rigorous studies need to be designed to understand which light colors and spectra are most effective at reducing fallout, taking into account potential taxon-specific differences.

Rescue protocols vary on the basis of the number of rescued birds, species-specific needs, and amount of resources allocated to the campaign (personnel, facilities, and materials). From rescue to release, every step should be evaluated to maximize the survival of rescued birds. For instance, different materials used for rescue boxes (including wood, wire net, plastic, or cardboard) could have different effects on the waterproofing capacities of the plumage. For some species, food and liquids are provided if individuals are under a predetermined bodymass threshold (Rodríguez et al. 2017). Finally, time from rescue to release may be critical (Rodríguez et al. 2012b, $2015 a, 2017)$, especially if veterinary care, liquids, or food are not provided. Thus, materials used in the boxes, body-mass thresholds, and release times should be based on scientific evidence.

After fledging, petrels spend several years at sea before returning to their breeding grounds. Because petrels generally breed underground, visit their colonies at night, and their colonies are generally difficult to access, 
Table 3. Mitigation measures to reduce effect of artificial light in areas close to seabird colonies.

\begin{tabular}{|c|c|c|c|c|}
\hline $\begin{array}{l}\text { Measures to } \\
\text { minimize artificial } \\
\text { light effects }\end{array}$ & Result & $\begin{array}{l}\text { Level of } \\
\text { effectiveness }\end{array}$ & Example & Reference \\
\hline $\begin{array}{l}\text { Banning external } \\
\text { lights; blinds on } \\
\text { windows with } \\
\text { internal lights }\end{array}$ & $\begin{array}{l}\text { prevents light } \\
\text { attraction and } \\
\text { window collision }\end{array}$ & high & $\begin{array}{l}\text { Shielding windows on St Kilda Island } \\
\text { reduced storm petrel strikes. } \\
\text { Removing external lighting and } \\
\text { requiring blinds to be closed at } \\
\text { night virtually eliminated night } \\
\text { strikes at South African research } \\
\text { stations on Gough and Marion } \\
\text { Islands. Similar measures on ships } \\
\text { offshore (external lights limited to } \\
\text { running lights only) also greatly } \\
\text { reduced collisions with vessels }\end{array}$ & $\begin{array}{l}\text { Cooper and Ryan } \\
\text { 1994; Miles } \\
\text { et al. 2010; P.G. } \\
\text { Ryan, personal } \\
\text { observation }\end{array}$ \\
\hline $\begin{array}{l}\text { Shielding the light } \\
\text { sources }\end{array}$ & $\begin{array}{l}\text { prevents light } \\
\text { escaping } \\
\text { upwards, } \\
\text { minimizing light } \\
\text { attraction }\end{array}$ & high & $\begin{array}{l}\text { Reduction of } 40 \% \text { of Puffinus } \\
\text { newelli groundings at a hotel. }\end{array}$ & Reed et al. 1985 \\
\hline $\begin{array}{l}\text { Reducing traffic } \\
\text { speed limits and } \\
\text { displaying } \\
\text { warning signals }\end{array}$ & $\begin{array}{l}\text { reduction of road } \\
\text { kills of seabirds } \\
\text { grounded by } \\
\text { lights }\end{array}$ & high & $\begin{array}{l}\text { Ardenna tenuirostris road kills were } \\
\text { reduced at sections of road under } \\
\text { management regulations. }\end{array}$ & $\begin{array}{l}\text { Rodríguez et al. } \\
\quad 2014\end{array}$ \\
\hline $\begin{array}{l}\text { Modification of light } \\
\text { characteristics }\end{array}$ & $\begin{array}{l}\text { prevents collision } \\
\text { and melatonin } \\
\text { suppression with } \\
\text { health and fitness } \\
\text { consequences }\end{array}$ & not assessed & $\begin{array}{l}\text { Several experiments report } \\
\text { inconclusive results in seabirds, for } \\
\text { example, for Puffinus newelli. } \\
\text { Several studies show negative } \\
\text { effect on other bird taxa. }\end{array}$ & $\begin{array}{l}\text { Reed 1986; Poot } \\
\text { et al. 2008; } \\
\text { Doppler et al. } \\
\text { 2015; Dominoni } \\
\text { et al. } 2016\end{array}$ \\
\hline $\begin{array}{l}\text { Change of rotating } \\
\text { beams of } \\
\text { lighthouses by } \\
\text { strobe or } \\
\text { intermittent } \\
\text { flashing signals }\end{array}$ & $\begin{array}{l}\text { minimizes light } \\
\text { attraction }\end{array}$ & not assessed & $\begin{array}{l}\text { Light attraction of birds has } \\
\text { decreased at flashing lights. }\end{array}$ & Montevecchi 2006 \\
\hline $\begin{array}{l}\text { Keep light intensity } \\
\text { as low as possible } \\
\text { on outside areas }\end{array}$ & $\begin{array}{l}\text { minimizes light } \\
\text { attraction and } \\
\text { potential } \\
\text { blindness caused } \\
\text { by too bright } \\
\text { lights } \\
\end{array}$ & not assessed & $\begin{array}{l}\text { In general, seabirds are grounded in } \\
\text { very brightly lit areas. }\end{array}$ & $\begin{array}{l}\text { Rodrigues et al. } \\
\text { 2012; Troy et al. } \\
2013\end{array}$ \\
\hline
\end{tabular}

unknown, or densely populated, following the fate of rescued birds is extraordinarily challenging. Ringing may help, especially in locations where monitoring programs are conducted on colonies. Satellite transmitters could be used to track and estimate survival of birds, at least during their first months at sea. Unfortunately, the high costs of satellite transmitters ( $>$ \$000 each) make large-sample projects prohibitively expensive.

Because most rescue campaigns are coordinated and carried out by people who are not scientists (e.g., 
local governments, environmental nongovernmental organizations, volunteers), analyses of their data are rarely published and scientific protocols are not followed rigorously. Combining rescue program information with rigorous scientific methods is crucial to better quantify the impact of light pollution on seabirds. Banding and tracking nestlings as they leave their natal colonies may improve understanding of maiden-flight characteristics (distances traveled, timing, or fatality areas [e.g., Rodríguez et al. 2015b]). Radar can also be used to monitor and quantify light attraction (e.g., Day et al. 2003, 2015). Remote sensing provides detailed information that has improved knowledge of the spatial distribution of light pollution (DMSP, VIIRS, EROS-B satellite imagery, or ISS photos [Kyba et al. 2014]), which is needed for a better assessment of light levels in the pathways to the ocean or colonies (Rodrigues et al. 2012; Troy et al. 2013; Rodríguez et al. 2015a). Despite the relatively large number of reports describing fallout patterns, further scientific studies should aim to unravel this problem, especially by focusing on rare species with limited biological information and on breeding grounds in different geographic locations (continental vs. insular, high vs. low altitude, coastal vs. inland, aggregated vs. sparse).

\section{Conclusions}

Artificial night lighting is a conservation problem for petrels; least 56 species are affected, including 24 classified as threatened on the IUCN Red List. However, light pollution affects other species, and determining the extent of the problem would be valuable. Without rescue programs, light pollution would have resulted in the death of at least 200,000 seabirds worldwide since rescue programs were established. Although light-related fatalities may be low relative to other human-induced mortality factors, such as bycatch and predation by introduced species, even a few light-related fatalities could have large negative effects on isolated seabird populations and endemic and endangered species (Gineste et al. 2016). Rescue programs are the most common mitigation measure used to reduce the risk of mortality once birds are grounded, but this action alone is insufficient to overcome the threat from artificial light. Avoidance and minimization measures are effective but are not commonly employed. Consideration of lighting impacts on seabirds should be included in the planning of new developments near petrel breeding areas (Table 3). Despite being a well-known problem for decades, understanding of why seabirds are attracted to lights and how best to mitigate light impacts is limited. More research is necessary to improve understanding of this human-wildlife conflict and to design appropriate and effective management and mitigation measures (Table 3). This is crucial given the critical conservation status of seabirds, particularly pe- trels (Croxall et al. 2012), and the ongoing global increase in light pollution (Falchi et al. 2016). Meanwhile, the general public and local governments should help reduce attraction to light and subsequent fatality through simple actions such as dimming, shading, or turning lights off at critical times of the year.

\section{Acknowledgments}

We are deeply grateful to those who kindly help rescue birds and to biologists, technicians, and project coordinators who coordinate rescue campaigns across the world and contribute to data collection. This research was supported by a Marie Curie Intra European Fellowship within the $7^{\text {th }}$ European Community Framework Programme (no. 330655 FP7-PEOPLE-2012-IOF).

\section{Supporting Information}

Information from rescue programs and anecdotal observations of species involved (Appendix S1), list of consulted organizations and researchers involved in rescue programs or studying seabird attraction to light (Appendix S2), IUCN list of Procellariiformes indicating whether they are burrow-nesting species and affected by artificial lights (Appendix S3), species assessments derived from our search of the IUCN Red List of Threatened Species website (Appendix S4), and a list of publications we identified on seabird mortality induced by marine- or land-based lights (Appendix S5). The authors are solely responsible for the content and functionality of these materials. Queries (other than absence of the material) should be directed to the corresponding author.

\section{Literature Cited}

Ainley DG, Podolsky R, Nur N, Deforest L, Spencer GA. 2001. Status and population trends of the Newell's shearwater on Kauai: a model for threatened petrels on urbanized tropical oceanic islands. Studies in Avian Biology 22:108-123.

Ainley DG, Walker W, Sencer GC, Holmes ND. 2014. The prey of Newell's shearwater Puffinus newelli in Hawaiian waters. Marine Ornithology 44:69-72.

Azam C, Kerbiriou C, Vernet A, Julien J-F, Bas Y, Plichard L, Maratrat J, Le Viol I. 2015. Is part-night lighting an effective measure to limit the impacts of artificial lighting on bats? Global Change Biology 21:4333-4341

Baccetti N, Sposimo P, Giannini F. 2005. Artificial lights and mortality of Cory's shearwater Calonectris diomedea on a Mediterranean island. Avocetta 29:89-91.

Bennie J, Duffy J, Davies T, Correa-Cano M, Gaston K. 2015. Global trends in exposure to light pollution in natural terrestrial ecosystems. Remote Sensing 7:2715-2730.

Black A. 2005. Light induced seabird mortality on vessels operating in the Southern Ocean: incidents and mitigation measures. Antarctic Science 17:67-68. 
Brooke M. 2004. Albatrosses and petrels across the world. Oxford University Press, Oxford, United Kingdom.

Cooper J, Ryan PG. 1994. Management Plan for the Gough Island Wildlife Reserve. Government of Tristan da Cunha, Edinburgh, Tristan da Cunha.

Croxall JP, Butchart SHM, Lascelles B, Stattersfield AJ, Sullivan B, Symes A, Taylor P. 2012. Seabird conservation status, threats and priority actions: a global assessment. Bird Conservation International 22:134.

Day J, Baker J, Schofield H, Mathews F, Gaston KJ. 2015. Part-night lighting: implications for bat conservation. Animal Conservation 18:512-516.

Day RH, Cooper BA, Telfer TC. 2003. Decline of Townsend's (Newell's) shearwaters (Puffinus auricularis newelli) on Kauai, Hawaii. Auk 120:669-679.

Day RH, Rose JR, Prichard AK, Streever B. 2015. Effects of gas flaring on the behavior of night-migrating birds at an artificial oil-production island, Arctic Alaska. Arctic 68:367-379.

Department of Justice. 2010. Kaua' $i$ island utility pleads guilty to endangered species act and migratory bird treaty act violation, agrees to help protect threatened seabirds. US Department of Justice. Available from https://www.justice.gov/opa/pr/kaua-i-island-utilitypleads-guilty-endangered-species-act-and-migratory-bird-treaty-act (accessed October 2016).

Dick MH, Donalson W. 1978. Fishing vessel endangered by crested auklet landings. Condor 80:235-236.

Dominoni DM, Borniger JC, Nelson RJ. 2016. Light at night, clocks and health: from humans to wild organisms. Biology Letters 12:20160015.

Doppler MS, Blackwell BF, DeVault TL, Fernández-Juricic E. 2015. Cowbird responses to aircraft with lights tuned to their eyes: Implications for bird-aircraft collisions. Condor 117:165-177.

Falchi F, Cinzano P, Duriscoe D, Kyba CCM, Elvidge CD, Baugh K, Portnov BA, Rybnikova NA, Furgoni R. 2016. The new world atlas of artificial night sky brightness. Science Advances 2:e1600377.

Fontaine R, Gimenez O, Bried J. 2011. The impact of introduced predators, light-induced mortality of fledglings and poaching on the dynamics of the Cory's shearwater (Calonectris diomedea) population from the Azores, northeastern subtropical Atlantic. Biological Conservation 144:1998-2011.

Gaston KJ, Duffy JP, Gaston S, Bennie J, Davies TW. 2014. Human alteration of natural light cycles: causes and ecological consequences. Oecologia 176:917-931.

Gaston KJ, Duffy JP, Bennie J. 2015a. Quantifying the erosion of natural darkness in the global protected area system. Conservation Biology 29:1132-1141.

Gaston KJ, Visser ME, Hölker F. 2015b. The biological impacts of artificial light at night: the research challenge. Philosophical Transactions of the Royal Society B: Biological Sciences 370:20140133.

Gineste B, Souquet M, Couzi F-X, Giloux Y, Philippe J-S, Hoarau C, Tourmetz J, Potin G, Le Corre M. 2016. Tropical shearwater population stability at Reunion Island, despite light pollution. Journal of Ornithology 158:385-394.

Glass JP, Ryan PG. 2013. Reduced seabird night strikes and mortality in the Tristan rock lobster fishery. African Journal of Marine Science 35:589-592.

Griesemer AM, Holmes ND. 2011. Newell's shearwater population modeling for HCP and recovery planning. Technical report. Pacific Cooperative Studies Unit, University of Hawaii, Manoa.

Hölker F, Wolter C, Perkin EK, Tockner K. 2010. Light pollution as a biodiversity threat. Trends in Ecology \& Evolution 25:681-682.

Holmes ND, Howald GR, Wegmann AS, Donlan CJ, Finkelstein M, Keitt B. 2016. The potential for biodiversity offsetting to fund invasive species eradications on islands. Conservation Biology 30:425427.

Imber MJ. 1975. Behaviour of petrels in relation to the moon and artificial lights. Notornis 22:302-306.
IUCN (International Union for Conservation of Nature) 2014. Biodiversity offsets technical study paper. IUCN, Gland, Switzerland.

IUCN (International Union for Conservation of Nature) 2016. The IUCN red list of threatened species. Version 2016-2. Cambridge, UK. Available from www.iucnredlist.org (accessed October 2016).

Kain EC, Lavers JL, Berg CJ, Raine AF, Bond AL. 2016. Plastic ingestion by Newell's (Puffinus newelli) and wedge-tailed shearwaters (Ardenna pacifica) in Hawaii. Environmental Science and Pollution Research 23:23951-23958.

KSHCP (Kaua'i Seabird Habitat Conservation Program) 2016. Lighting for homes and business. KSHCP, Kaua'i. Available from http://kauaiseabirdhcp.com/lighting-homes-businesses/ (accessed October 2016).

Kyba CCM, Garz S, Kuechly H, de Miguel AS, Zamorano J, Fischer J, Hölker F. 2014. High-resolution imagery of earth at night: new sources, opportunities and challenges. Remote Sensing 7:1-23.

Laguna JM, Barbara N, Metzger B. 2014. Light pollution impact on "tubenose" seabirds: an overview of areas of concern in the Maltese Islands. BirdLife Malta, Xemxija. Available from http:// birdlifemalta.org/wp-content/uploads/2016/08/BLM-Light -Pollution-Report-2014.pdf (accessed 10 October 2016).

Le Corre M, Ollivier A, Ribes S, Jouventin P. 2002. Light-induced mortality of petrels: a 4-year study from Réunion Island (Indian Ocean). Biological Conservation 105:93-102.

Le Corre M, Ghestemme T, Salamolard M, Couzi F-X. 2003. Rescue of the Mascarene Petrel, a critically endangered seabird of Réunion Island, Indian Ocean. Condor 105:387-391.

Longcore T, Rich C. 2004. Ecological light pollution. Frontiers in Ecology and the Environment 2:191-198.

Merkel FR, Johansen KL. 2011. Light-induced bird strikes on vessels in Southwest Greenland. Marine Pollution Bulletin 62:2330-2336.

Miles W, Money S, Luxmoore R, Furness RW. 2010. Effects of artificial lights and moonlight on petrels at St Kilda. Bird Study 57: 244-251.

Montevecchi WA. 2006. Influences of artificial light on marine birds. Pages 94-113 in Rich C, Longcore T, editors. Ecological consequences of artificial night lighting. Island Press, Washington, D.C.

Murillo Y, Piana RP, Delgado-Alburqueque L. 2013. Rescate de Golondrinas de la Tempestad de Collar (Oceanodroma hornbyi) en la ciudad de Lima, Perú. Boletín de Ornitología Peruana-UNOP 8:5564.

Podolsky R, Ainley D, Spencer G, Deforest L, Nur N. 1998. Mortality of Newell's shearwaters caused by collisions with urban structures on Kauai. Colonial Waterbirds 21::20-34.

Poot H, Ens BJ, de Vries H, Donners MAH, Wernand MR, Marquenie JM. 2008. Green light for nocturnally migrating birds. Ecology and Society 13:47.

Reed JR. 1986. Seabird Vision: spectral sensitivity and light attraction behavior. PhD dissertation. University of Wisconsin, Madison.

Reed JR. 1987. Polarizing filters fail to reduce light attraction in Newell's Shearwaters. Wildlife Society Bulletin 15:596-598.

Reed JR, Sincock JL, Hailman JP. 1985. Light attraction in endangered Procellariiform birds: reduction by shielding upward radiation. Auk 102:377-383.

Riethmuller M, Jan F, Giloux Y, Saliman M. 2012. Plan national d'actions en faveur du Pétrel noir de Bourbon Pseudobulweria aterima (2012-2016). Ministère de l'Écologie, du Développement durable et de l'Energie, Direction de l'Environnement, de l'Aménagement et du Logement de La Réunion, Sant-Denis.

Rodrigues P, Aubrecht C, Gil A, Longcore T, Elvidge C. 2012. Remote sensing to map influence of light pollution on Cory's shearwater in São Miguel Island, Azores Archipelago. European Journal of Wildlife Research 58:147-155.

Rodríguez A, Burgan G, Dann P, Jessop R, Negro JJ, Chiaradia A. 2014. Fatal attraction of short-tailed shearwaters to artificial lights. PLOS ONE 9 (e110114) https://doi.org/10.1371/journal.pone.0110114. 
Rodríguez A, Rodríguez B. 2009. Attraction of petrels to artificial lights in the Canary Islands: effect of the moon phase and age class. Ibis 151:299-310.

Rodríguez A, Rodríguez B, Barone R, Pérez B, Hernández A. 2008. Status and conservation requirements of Manx shearwaters Puffinus puffinus on Tenerife (Canary Islands). Alauda 76:72-74.

Rodríguez A, Rodríguez B, Carrasco MN. 2012a. High prevalence of parental delivery of plastic debris in Cory's shearwaters (Calonectris diomedea). Marine Pollution Bulletin 64:22192223.

Rodríguez A, Rodríguez B, Curbelo ÁJ, Pérez A, Marrero S, Negro JJ. $2012 b$. Factors affecting mortality of shearwaters stranded by light pollution. Animal Conservation 15:519-526.

Rodríguez A, Rodríguez B, Lucas MP. 2012c. Trends in numbers of petrels attracted to artificial lights suggest population declines in Tenerife, Canary Islands. Ibis 154:167-172.

Rodríguez A, García D, Rodríguez B, Cardona E, Parpal L, Pons P. $2015 a$. Artificial lights and seabirds: Is light pollution a threat for the threatened Balearic petrels? Journal of Ornithology 156:893-902.

Rodríguez A, Rodríguez B, Negro JJ. 2015b. GPS tracking for mapping seabird mortality induced by light pollution. Scientific Reports 5(10670) https://doi.org/10.1038/srep10670.

Rodríguez A, Moffet J, Revoltós A, Wasiak P, McIntosh RR, Sutherland DR, Renwick L, Dann P, Chiaradia A. 2017. Light pollution and seabird fledglings: targeting efforts in rescue programs. Journal of Wildlife Management 81:734-741.

Ronconi RA, Allard KA, Taylor PD. 2015. Bird interactions with offshore oil and gas platforms: review of impacts and monitoring techniques. Journal of Environmental Management 147:34-45.

Ryan PG. 1991. The impact of the commercial lobster fishery on seabirds at the Tristan da Cunha islands, South Atlantic Ocean. Biological Conservation 57:339-350.

Salamolard M, Ghestemme T, Couzi F-X, Minatchy N, Le Corre M. 2007. Impacts des éclairages urbains sur les petrels de Barau, Pterodroma baraui sur I'lle de la Réunion et measures pour réduire ces impacts. Ostrich 78:449-452.

Simons TR. 1984. A population model of the endangered Hawaiian dark-rumped petrel. Journal of Wildlife Management 84:1065-1076.

Telfer TC, Sincock JL, Byrd GV, Reed JR. 1987. Attraction of Hawaiian seabirds to lights: conservation efforts and effects of moon phase. Wildlife Society Bulletin 15:406-413.

The Associated Press. 2010. In Hawaii, birds' Friday night flights turn out the lights on prep games. New York Times 23 October. Available from http://www.nytimes.com/2010/10/24/sports/24birds. html (accessed October 2016).

The Biodiversity Consultancy. 2016. Mitigation Hierarchy. The Biodiversity Consultancy, Cambridge, United Kingdom. Available from http://www.thebiodiversityconsultancy.com/approaches/ mitigation-hierarchy/ (accessed October 2016).

Troy JR, Holmes ND, Green MC. 2011. Modeling artificial light viewed by fledgling seabirds. Ecosphere 2(109) https://doi.org/ 10.1890/ES11-00094.1.

TroyJR, Holmes ND, Veech JA, Green MC. 2013. Using observed seabird fallout records to infer patterns of attraction to artificial light. Endangered Species Research 22:225-234.

Villard P, Dano S, Bretagnolle V. 2006. Morphometrics and the breeding biology of the Tahiti Petrel Pseudobulweria rostrata. Ibis 148:285291.

Whitworth DL, Takewaka JY, Carter HR, McIver WR. 1997. A nightlighting technique for at-sea capture of Xantus' murrelets. Colonial Waterbirds 20:525-531.

Wiese FK, Montevecchi WA, Davoren GK, Huettmann F, Diamond AW. 2001. Seabirds at risk around offshore oil platforms in the Northwest Atlantic. Marine Pollution Bulletin 42:1285-1290.

Wilhelm SI, Schau JJ, Schau E, Suzanne M, Wiseman DL, Hogan HA, Dooley SM. 2013. Atlantic Puffins are attracted to coastal communities in Eastern Newfoundland. Northeast Naturalist 20:624-630. 